\title{
Regresi Data Panel dengan Pendekatan Common Effect Model (CEM), Fixed Effect model (FEM) dan Random Effect Model (REM) \\ (Studi Kasus: Persentase Penduduk Miskin Menurut Kabupaten/Kota di Kalimantan Timur Tahun 2015-2018)
}

\author{
Eka Nur Amaliah ${ }^{1 *}$, Darnah $^{2}$, Sifriyani $^{3}$ \\ 1,2,3 Departemen Statistika, Fakultas MIPA, \\ Universitas Mulawarman, Samarinda, 75119, Indonesia \\ * Corresponding author, email: ekanuramaliah2805@gmail.com
}

\begin{abstract}
Panel data regression is a regression that combines cross section data and time series data. Panel data regression estimation can be done through 3 estimates namely CEM, FEM and REM. This research will make a modeling of the percentage of poor people according to regencies / cities in East Kalimantan using panel data regression analysis. Poverty occurs due to lack of income and assets to meet basic needs. For this reason, variables that are assumed to affect the percentage of the poor are used, including the Population Growth Rate (LPP), Human Development Index (HDI), and Adjustable Per capita Expenditure (PPD). By using 3 CEM, FEM and REM approaches based on testing, the best FEM model is obtained. Based on the FEM model the factors that significantly influence are the HDI and PPD. A value of 0.7755 means that the HDI and PPD can explain the percentage of poor people according to the Regency / City in East Kalimantan of $77.55 \%$ while the remaining $22.45 \%$ is influenced by other variables not yet included in the model.
\end{abstract}

Keywords: CEM, FEM, Panel Data Regression, Poverty, and REM.

\begin{abstract}
Abstrak
Regresi data panel merupakan regresi yang menggabungkan data cross section dan data time series. Estimasi regresi data panel dapat dilakukan melalui 3 estimasi yakni CEM, FEM dan REM. Pada peneltian ini akan dibuat pemodelan persentase penduduk miskin menurut Kabupaten/Kota di Kalimantan Timur menggunakan analisis regresi data panel. Kemiskinan terjadi diakibatkan karena kurangnya pendapatan dan aset untuk memenuhi kebutuhan dasar. Atas dasar tersebut maka digunakan variabel yang diasumsikan mempengaruhi persentase penduduk miskin diantaranya Laju Pertumbuhan Penduduk (LPP), Indeks Pembangunan Manusia (IPM), dan Pengeluaran Perkapita Disesuaikan (PPD). Dengan menggunakan 3 pendekatan CEM, FEM dan REM berdasarkan pengujian didapatkan model FEM yang terbaik. Berdasarkan model FEM faktor yang berpengaruh signifikan adalah IPM dan PPD. Nilai sebesar 0,7755 artinya IPM dan PPD dapat menjelaskan persentase penduduk miskin menurut Kabupaten/Kota di Kalimantan Timur sebesar 77,55\% sedangkan sisanya 22,45\% dipengaruhi oleh variabel lain yang belum masuk ke dalam model.
\end{abstract}

Kata Kunci: CEM, FEM, Kemiskinan, Regresi Data Panel dan REM.

Estimasi: Journal of Statistics and Its Application

e-ISSN: 2721-3803, p-ISSN: 2721-379X

http://journal.unhas.ac.id/index.php/ESTIMASI 


\section{Pendahuluan}

Analisis regresi merupakan metode statistika yang digunakan untuk mempelajari dan mengukur hubungan statistik yang terjadi antara dua atau lebih variabel [6]. Jenis data yang biasanya digunakan pada analisis regresi umumnya adalah data cross section. Namun beberapa observasi perilaku unit ekonomi seperti rumah tangga, perusahaan atau negara, data observasi yang digunakan tidak hanya dilakukan pada unit-unit dalam waktu tertentu tetapi juga dilakukan pada unit-unit dalam periode waktu tertentu. Sehingga munculah gabungan data cross section dan data time series yang disebut data pooling atau data panel [8].

Analisis regresi yang menggunakan data panel disebut model regresi data panel. metode regresi data panel mempunyai beberapa keuntungan diantaranya adalah data panel merupakan gabungan dua data time series dan cross section mampu menyediakan data yang lebih banyak sehingga akan menghasilkan degree of freedom yang lebih besar. Menggabungkan informasi dari data time series dan cross section dapat mengatasi masalah yang timbul ketika ada masalah penghilangan variabel (ommitedvariable) [10].

Pada model regresi data panel terdapat 3 macam estimasi yakni Common Effect Model (CEM), Fixed Effect Model (FEM) dan Random Effect Model (REM). CEM adalah pendugaan yang menggabungkan (pooled) seluruh data time series dan cross section dan menggunakan pendekatan Ordinary Least Square (OLS) untuk menduga parameternya. Metode OLS merupakan salah satu metode populer untuk menduga nilai parameter dalam persamaan regresi linier. FEM adalah Pendugaan parameter regresi panel dengan menggunakan teknik penambahan variabel dummy sehingga metode ini seringkali disebut dengan Least Square Dummy Variable Model [1]. Sedangkan pada REM, efek individu diasumsikan bersifat random. REM lebih tepat diestimasi dengan metode generalized least square (GLS) karena adanya potensi korelasi antara variabel gangguan dalam persamaan [11].

Kemiskinan merupakan permasalahan negara berkembang yang sulit terpecahkan. Hampir setiap daerah di Indonesia masih menjadikan kemiskinan sebagai salah satu persoalan di bidang ekonomi. Selain itu, kemiskinan merupakan salah satu parameter kondisi sosial ekonomi dalam menilai keberhasilan pembangunan di suatu daerah. Menurut Badan Pusat Statistik (BPS) tahun 2019 kemiskinan merupakan suatu kondisi dimana tingkat pendapatan yang dianggap perlu dipenuhi untuk memperoleh standar hidup masih minim [2]. Kemiskinan dapat diakibatkan dengan kurangnya pendapatan dan aset untuk memenuhi kebutuhan dasar. Kebutuhan dasar ini adalah berupa pangan, sandang, dan papan. Kemiskinan dapat pula berkaitan dengan keterbatasan lapangan pekerjaan atau pengangguran, akses pendidikan dan kesehatan yang tidak memadai. Upaya mengatasi masalah kemiskinan ini tidak dapat dilakukan 
secara terpisah dari kondisi ekonomi, pendidikan, kesehatan dan masalah kompleks lain yang berkaitan dengan kemiskinan [12] dan indeks pembangunan manusia [13].

Pada penelitian ini akan dibahas pemodelan regresi data panel. Studi kasus yang digunakan adalah data persentase penduduk miskin yang ada di Kalimantan Timur menurut Kabupaten/Kota untuk periode 2015-2018. Variabel yang diasumsikan mempengaruhi persentase penduduk miskin diantaranya Laju Pertumbuhan Penduduk (LPP), Indeks Pembangunan Manusia (IPM), dan Pengeluaran Perkapita Disesuaikan (PPD).

\section{Material dan Metode}

Data yang digunakan pada penelitian ini adalah data sekunder yang bersumber dari Badan Pusat Statistik Provinsi Kalimantan Timur. Data yang diambil adalah 10 Kabupaten/Kota di Kalimnatan Timur pada Tahun 2015 sampai dengan 2018. Variabel dalam penelitian ini terdiri dari 1 variabel dependen dan 3 variabel independen. Variabel Persentase Penduduk Miskin sebagai variabel dependen ( $Y$ ), laju pertumbuhan penduduk, indeks pembangunan manusia dan pengeluaran perkapita disesuaikan sebagai variabel independen $\left(X_{1}, X_{2}, X_{3}\right)$, Penelitian ini dibantu menggunakan paket software R.

Data panel atau pooled data adalah kombinasi dari data time series dan cross section. Jumlah observasi akan bertambah secara signifikan tanpa melakukan treatment apapun terhadap data. Dengan mengakomodasi informasi baik yang terkait dengan variabel-variabel cross section maupun time series, data panel secara subtansial mampu menurunkan masalah omitted variable atau mengabaikan variabel yang relevan [5].

\subsection{Model Regresi Data Panel}

Regresi data panel adalah regresi yang menggunakan data pengamatan terhadap satu atau lebih variabel pada unit secara terus menerus selama beberapa periode waktu [7]. Model regresi data panel memeriksa pengaruh unit cross section, pengaruh unit time series atau keduanya untuk mengatasi pengaruh heterogen yang mungkin teramati atau tidak teramati. Pengaruh-pengaruhnya adalah pengaruh tetap (fixed effect) atau pengaruh acak (random effect). Fixed effect diperiksa jika intersep bervariasi antar unit cross section atau unit time series. Sementara random effect diperiksa jika terdapat perbedaan komponen varians galat antar unit cross section dan unit time series [9].

Model regresi data panel secara umum [3] ditunjukkan pada persamaan (1).

$$
Y_{i t}=\beta_{0_{i t}}+\mathbf{x}_{\mathrm{it}} \boldsymbol{\beta}+\varepsilon_{i t} ; i=1,2, \ldots, N ; t=1,2, \ldots, T
$$

\subsection{Estimasi Model Regresi Data Panel}

Terdapat tiga cara estimasi pada model regresi data panel, yakni Common Effect Model (CEM), Fixed Effect Model (FEM) dan Random Effect Model (REM). 


\section{Common Effect Model (CEM)}

Pada model Common Effect Model (CEM) seluruh data digabungkan tanpa mempertimbangkan waktu dan individu sehingga hanya mempunyai satu data yang terdiri dari variabel dependen dan variabel-variabel independen. Sehingga model ini sama seperti model regresi linear pada umumnya [8].

Persamaan model untuk CEM ditunjukkan pada persmaan (2).

$$
Y_{i t}=\beta_{0}+\mathbf{x}_{\mathrm{it}} \boldsymbol{\beta}+\varepsilon_{i t} ; i=1,2, \ldots, N ; t=1,2, \ldots, T
$$

dimana:

$Y_{i t} \quad=$ nilai variabel dependen unit cross section ke- $i$ untuk periode ke- $t$

$\beta_{0} \quad=$ intersep atau konstanta unit cross section

$\mathbf{x}_{\mathbf{i t}} \quad=\left[\begin{array}{llll}x_{1_{i t}} & x_{2_{i t}} \ldots & x_{k_{i t}}\end{array}\right]$ vektor variabel independen berukuran $(1 \mathrm{x} k)$

$\boldsymbol{\beta}^{\prime}=\left[\beta_{1} \beta_{2} \ldots \beta_{k}\right]$ vektor slope atau koefisien regresi sebanyak $k$ variabel independen berukuran $(k \times 1)$

$\varepsilon_{i t} \quad=$ galat regresi unit cross section ke- $i$ untuk periode ke- $t ; \varepsilon_{i t} \sim N\left(0, \sigma_{\varepsilon}^{2}\right)$

\section{Fixed Effect Model (FEM)}

Salah satu cara memperhatikan heterogenitas unit cross-section pada model regresi data panel adalah dengan membeda-bedakan nilai intersep namun slope konstan [4]. Model ini dikenal dengan Fixed Effect Model (FEM), persamaannya ditunjukkan pada persamaan (3).

$$
Y_{i t}=\beta_{0_{i}}+\mathbf{x}_{\mathrm{it}} \boldsymbol{\beta}+\varepsilon_{i t}
$$

dimana:

$Y_{i t} \quad=$ nilai variabel dependen unit cross section ke- $i$ untuk periode ke- $t$

$\beta_{0_{i}} \quad=$ intersep atau konstanta unit cross section ke- $i$

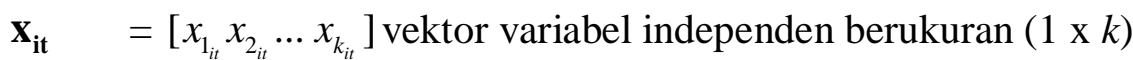

$\boldsymbol{\beta}^{\prime}=\left[\beta_{1} \beta_{2} \ldots \beta_{k}\right]$ vektor slope atau koefisien regresi sebanyak $k$ variabel independen berukuran $(k \times 1)$

$\varepsilon_{i t} \quad=$ galat regresi unit cross section ke- $i$ untuk periode ke- $t ; \varepsilon_{i t} \sim N\left(0, \sigma_{\varepsilon}^{2}\right)$

\section{Random Effect Model (REM)}

Pendekatan dengan model random efek (REM) diasumsikan $\beta_{0_{i}}$ merupakan variabel random dengan mean $\bar{\beta}_{0}$ dan variansi $\sigma_{\varepsilon}^{2}$ [11]. Sehingga intersep ditunjukkan pada persamaan (4).

$$
\beta_{0_{i}}=\bar{\beta}_{0}+\varepsilon_{i} ; \varepsilon_{i} \sim N_{i i d}\left(0, \sigma_{\varepsilon}^{2}\right)
$$


Dengan $\varepsilon_{i}$ merupakan galat random yang mempunyai mean 0 dan variansi $\sigma_{\varepsilon}^{2}$. Model efek acak dapat diestimasi dengan metode Generalized Least Square (GLS) sebab jika diestimasi dengan OLS hasil estimasi tidak efisien [4]. Secara umum persamaan model efek acak ditunjukkan pada persamaan (5).

$$
Y_{i t}=\beta_{0}+\mathbf{x}_{\mathrm{it}} \boldsymbol{\beta}+w_{i t}
$$

dimana $w_{i t}$ ditunjukkan pada persamaan (6)

$$
w_{i t}=\varepsilon_{i}+u_{i t} ; w_{i t} \sim N_{i i d}\left(0, \sigma_{w}^{2}\right)
$$

Nilai $w_{i t}$ mengandung galat untuk data cross section $\left(\varepsilon_{i}\right)$ dan untuk data berkala $\left(u_{i t}\right)$ dengan asumsi bersifat independent and identically distributed (IID) normal dengan mean 0 dan variansi $\sigma_{w}^{2}[4]$.

\section{Hasil dan Diskusi}

\subsection{Analisis Statistika Deskriptif}

Gambaran variabel dependen dan independen yang digunakan secara umum disajikan pada Tabel 1 sebagai berikut:

Tabel 1. Gambaran data berdasarkan variabel dependen dan independen tahun 20152018

\begin{tabular}{lrrrrrr}
\hline \multicolumn{1}{c}{ Variabel } & N & Rata-Rata & Median & Minimum & Maksimum & $\begin{array}{r}\text { Standar } \\
\text { Deviasi }\end{array}$ \\
\hline Y $(\%)$ & 40 & 7,10 & 7,600 & 2,640 & 11,620 & 2,46 \\
X $_{1}(\%)$ & 40 & 1,93 & 2,030 & 0,160 & 4,280 & 1,08 \\
X $_{2}$ (indeks) & 40 & 73,19 & 72,050 & 64,890 & 79,930 & 4,42 \\
X $_{3}$ (Ribu Rp) & 40 & 11,54 & 10,936 & 7,162 & 16,698 & $2.529,12$ \\
\hline
\end{tabular}

Berdasarkan Tabel 4.1, diperoleh bahwa persentase penduduk miskin menurut Kabupaten/Kota di Kalimantan Timur mempunyai nilai rata-rata 7,10\% dengan standar deviasi 2,46\%. Kabupaten/Kota yang memiliki persentase penduduk miskin terendah adalah Kota Balikpapan sedangkan persentase penduduk miskin tertinggi adalah Kabupaten Mahakam Ulu.

Rata-rata laju pertumbuhan penduduk $1,93 \%$ dengan standar deviasi 1,08\%. Kabupaten/Kota yang memiliki laju petumbuhan penduduk terendah adalah Kabupaten Mahakam Ulu sedangkan laju pertumbuhan penduduk tertinggi adalah Kabupaten Kutai Timur. Rata-rata indeks pembangunan manusia adalah 73,19 dengan standar deviasi 4,42. Kabupaten/Kota yang memiliki indeks pembangunan manusia yang terendah adalah Kabupaten Mahakam Ulu sedangkan indeks pembangunan manusia yang tertinggi adalah Kota Samarinda. Rata-rata pengeluaran perkapita adalah 11.539 Ribu Rupiah dengan standar deviasi 2.529,12 Ribu Rupiah. Kabupaten/Kota yang memiliki 
pengeluaran perkapita disesuaikan yang terendah adalah Kabupaten Mahakam Ulu sedangkan pengeluaran perkapita disesuaikan yang tertinggi yakni Kota Bontang.

\subsection{Estimasi Model Regresi Data Panel}

1. Common Effect Model (CEM)

Model regresi data panel pada data persentase penduduk miskin diestimasi dengan Common Effect Model (CEM) ditunjukkan pada persamaan (7).

$$
\hat{Y}_{i t}=39,8875+0,2471 X_{1_{i t}}-0,4297 X_{2_{i t}}-0,0002 X_{3_{i t}}
$$

\section{Fixed Effect Model (FEM)}

Model regresi data panel pada data persentase penduduk miskin diestimasi dengan Fixed Effect Model (FEM) ditunjukkan pada persamaan (8).

$$
\begin{aligned}
\hat{Y}_{i t}= & 0,231 X_{1_{i t}}+0,500 X_{2_{i t}}-0,001 X_{3_{i t}}-19,542 D_{\text {Berau }} \\
& -17,945 D_{\text {Bontang }}-22,153 D_{B P P}-16,336 D_{\text {Kubar }}-17,928 D_{\text {Kukar }} \\
& -16,822 D_{\text {Kutim }}-14,220 D_{\text {Mahulu }}-16,292 D_{\text {Paser }}-16,031 D_{P P U} \\
& -20,433 D_{S M D}
\end{aligned}
$$

\section{Random Effect Model (REM)}

Model regresi data panel pada data persentase penduduk miskin diestimasi dengan Random Effect Model (REM) ditunjukan pada persamaan (9).

$$
\hat{Y}_{i t}=-5,699-0,218 X_{1_{i t}}+0,367 X_{2_{i t}}-0,001 X_{3_{i t}}
$$

\subsection{Penentuan Model Estimasi Regresi Data Panel}

1. Uji Chow

Pengujian ini dilakukan untuk mengetahui apakah teknik regresi data panel dengan model FEM lebih baik daripada model CEM. Berdasarkan hasil pengujian didapatkan $p$ value sebesar 2,2 $\times 10^{-16}$ dan lebih kecil dari $\alpha=5 \%$ maka diputuskan $H_{0}$ ditolak. Berdasarkan pengujian tersebut maka model estimasi yang baik antara CEM dan FEM adalah model FEM.

2. Uji Hausman

Pengujian ini dilakukan untuk mengetahui apakah sebaiknya model REM atau FEM yang digunakan. Berdasarkan hasil pengujian didapatkan p-value sebesar 0,000 dan lebih kecil dari $\alpha=5 \%$ maka diputuskan $H_{0}$ ditolak. Berdasarkan pengujian tersebut maka model estimasi yang baik antara REM dan FEM adalah model FEM. Sehingga model regresi data panel diestimasi dengan FEM unit cross section atau individu (Kabupaten/Kota). 


\subsection{Pengujian Signifikansi Parameter}

Model regresi data panel yang sesuai untuk data persentase penduduk miskin Kabupaten/Kota di Kalimantan Timur adalah diestimasi dengan Fixed Effect Model (FEM). Setelah didapatkan model estimasi yang digunakan yakni model FEM sesuai dengan persamaan (8), maka dilakukan pengujian signifikansi parameter baik secara serentak maupun parsial.

1. Uji Serentak

Berdasarkan hasil pengujian didapatkan nilai $F$ sebesar 312,140 dan lebih besar dari $F_{(12) ;(27) ; 0,05}=2,13$ maka diputuskan $H_{0}$ ditolak artinya secara serentak terdapat pengaruh yang signifikan antara variabel independen terhadap variabel dependen.

2. Uji Parsial

Berdasarkan hasil pengujian didapatkan nilai probabilitas statistik $t$ dan kesimpulan disajikan pada tabel 2 sebagai beikut:

Tabel 2. Uji Parsial

\begin{tabular}{lccc}
\hline Variabel & Koefisien & $p$-value & Kesimpulan \\
& & & \\
\hline X $_{1}$ (Laju Pertumbuhan Penduduk) & 0,231 & 0,594 & Tidak Berpengaruh \\
X $_{2}$ (Indeks Pembangunan Manusia) & 0,500 & 0,023 & Berpengaruh \\
X $_{3}$ (Pengeluaran Perkapita Disesuaikan) & $-0,001$ & 0,035 & Berpengaruh \\
\hline
\end{tabular}

Berdasarkan Tabel 2 didapatkan bahwa pada taraf signifikansi $\alpha=5 \%$ variabel laju pertumbuhan penduduk tidak berpengaruh signifikan terhadap variabel persentase penduduk miskin, sedangkan variabel indeks pembangunan manusia dan pengeluaran perkapita disesuaikan berpengaruh signifikan terhadap variabel persentase penduduk miskin. Variabel dummy yang signifikan yakni D8 (Kabupaten Paser) dan D9 (Kabupaten Penajam Paser Utara)

Hasil estimasi model Fixed Effect Model (FEM) dengan variabel independen dan variabel dummy yang berpengaruh signifikan disajikan pada Tabel 3 berikut:

Tabel 3. Hasil Estimasi Model FEM dengan Variabel Independen dan Variabel Dummy yang Berpengaruh Signifikan

\begin{tabular}{cc}
\hline Variabel & Koefisien \\
\hline$X_{2}$ & 0,500 \\
$X_{3}$ & $-0,001$ \\
$D_{\text {paser }}$ & $-4,209$ \\
$D_{P P U}$ & $-2,488$ \\
\hline
\end{tabular}

Dari Tabel 3 maka diperoleh model estimasi FEM dengan variabel independen dan variabel dummy yang berpengaruh signifikan ditunjukkan pada persamaan (10).

$$
\hat{Y}_{i t}=0,500 X_{2_{i t}}-0,001 X_{3_{i t}}-4,209 D_{\text {Paser }}-2,488 D_{P P U}
$$


Model (10) dapat diinterpretasikan bahwa jika nilai Indeks Pembangunan Manusia (IPM) mengalami kenaikan sebesar 1 satuan dan perubahan nilai variabel pengeluaran perkapita disesuaikan tetap maka akan meningkatkan persentase penduduk miskin sebesar 0,500\% dan bertambahnya Pengeluaran Perkapita Disesuaikan (PPD) sebesar 1 Ribu Rupiah dan perubahan nilai variabel indeks pembangunan manusia tetap maka akan menurunkan persentase penduduk miskin sebesar 0,001\%. Kemudian $D_{\text {Paser }}$ akan mengalami penurunan kemiskinan sebesar 4,209\% ketika persentase kemiskinan Kabupaten/Kota lainnya 0 dan $D_{P P U}$ akan mengalami penurunan kemiskinan sebesar 2,488\% ketika persentase kemiskinan Kabupaten/Kota lainnya 0.

\subsection{Deteksi Penyimpangan Asumsi Klasik}

1. Deteksi Multikolinearitas

Pengujian asumsi multikolinearitas dapat dilakukan dengan uji VIF. Berdasarkan hasil pengujian didapatkan nilai VIF sebesar $12,135>10$ artinya terjadi multikolinearitas pada model FEM. Sehingga model FEM tidak memenuhi asumsi non multikolinearitas.

2. Deteksi Heteroskedastisitas

Pengujian asumsi heteroskedastisitas dapat dilakukan dengan uji BreuschPagan.(BP) Berdasarkan hasil pengujian didapatkan nilai p-value sebesar 0,096 lebih besar dari $\alpha=5 \%$ maka diputuskan $H_{0}$ diterima artinya model FEM memenuhi asumsi non heteroskedastisitas (memenuhi asumsi homoskedastisitas).

3. Deteksi Otokorelasi

Pengujian asumsi otokorelasi dapat dilakukan dengan uji Durbin-Watson (DW). Berdasarkan hasil pengujian didapatkan nilai $p$-value sebesar 1,143 lebih besar dari $\alpha=5 \%$ maka diputuskan $H_{0}$ diterima artinya model FEM memenuhi asumsi non otokorelasi.

4. Deteksi Normalitas

Pengujian asumsi normalitas dapat dilakukan dengan uji Jarque-Bera (JB). Berdasarkan hasil pengujian didapatkan nilai $p$-value sebesar 0,126 lebih besar dari $\alpha=5 \%$ maka diputuskan $H_{0}$ diterima artinya model FEM memiliki galat yang berdistribusi normal.

5. Mengatasi Multikolinearitas

Berdasarkan hasil pengujian didapatkan nilai VIF sebesar 12,135>10 artinya terjadi multikolinearitas pada model FEM. Sehingga untuk mengatasi multikolinearitas dilakukan dengan transformasi variabel ke dalam bentuk diferensi pertama (first difference). Kemudian berdasarkan hasil pengujian asumsi kembali didapatkan nilai VIF sebesar 7,808 dan lebih kecil dari 10 artinya tidak terjadi multikolinearitas pada model FEM. Sehingga model FEM memenuhi asumsi non multikolinearitas. 


\section{Koefisien Determinasi}

Berdasarkan hasil pengujian didapatkan nilai koefisien determinasi $\left(R^{2}\right)$ adalah sebesar 0,7755. Nilai ini memiliki arti bahwa Indeks Pembangunan Manusia dan Pengeluaran Perkapita Disesuaikan dapat menjelaskan persentase penduduk miskin menurut Kabupaten/Kota di Kalimantan Timur sebesar $77,55 \%$ sedangkan sisanya $22,45 \%$ dipengaruhi oleh variabel-variabel lain yang belum masuk dalam model.

\subsection{Model Akhir Regresi Data Panel}

Berdasarkan pengujian yang telah dilakukan diperoleh model regresi data panel untuk persentase penduduk miskin menurut Kabupaten/Kota di Kalimantan Timur yaitu model estimasi Fixed Effect Model (FEM) setelah dilakukan transformasi ke dalam bentuk first difference pada variabel Persentase Penduduk Miskin (Y), Indeks Pembangunan Manusia $\left(X_{2}\right)$, Pengeluaran Perkapita Disesuaikan $\left(\mathrm{X}_{3}\right)$ dan variabel dummy tidak ada yang signifikan sehingga tidak dimasukkan ke dalam model ditunjukkan pada persamaan (11).

$$
\hat{Y}_{i t}=\hat{\beta}_{0_{i}}-0,363 X_{2_{i t}}-0,001 X_{3_{i t}}
$$

Model (11) dapat diinterpretasikan bahwa jika nilai Indeks Pembangunan Manusia (IPM) mengalami kenaikan sebesar 1 satuan dan perubahan nilai variabel pengeluaran perkapita disesuaikan tetap maka akan menurunkan persentase penduduk miskin sebesar 0,363\% dan bertambahnya Pengeluaran Perkapita Disesuaikan (PPD) sebesar 1 Ribu Rupiah dan perubahan nilai variabel indeks pembangunan manusia tetap maka akan menurunkan persentase penduduk miskin sebesar $0,001 \%$.

\section{Kesimpulan}

Berdasarkan hasil penelitian didapatkan kesimpulan sebagai berikut:

a) Model regresi data panel pada data persentase penduduk miskin diestimasi dengan Common Effect Model (CEM) adalah sebagai berikut:

$$
\hat{Y}_{i t}=39,8875+0,2471 X_{1_{i t}}-0,4297 X_{2_{i t}}-0,0002 X_{3_{i t}}
$$

b) Model regresi data panel pada data persentase penduduk miskin diestimasi dengan Fixed Effect Model (FEM) adalah sebagai berikut:

$$
\begin{aligned}
\hat{Y}_{i t}= & 0,231 X_{1_{i t}}+0,500 X_{2_{i t}}-0,001 X_{3_{i t}}-19,542 D_{\text {Berau }} \\
& -17,945 D_{\text {Bontang }}-22,153 D_{B P P}-16,336 D_{\text {Kubar }}-17,928 D_{\text {Kukar }} \\
& -16,822 D_{\text {Kutim }}-14,220 D_{\text {Mahulu }}-16,292 D_{\text {Paser }}-16,031 D_{P P U} \\
& -20,433 D_{\text {SMD }}
\end{aligned}
$$

c) Model regresi data panel pada data persentase penduduk miskin diestimasi dengan Random Effect Model (REM) adalah sebagai berikut:

$$
\hat{Y}_{i t}=-5,699-0,218 X_{1_{i t}}+0,367 X_{2_{i t}}-0,001 X_{3_{i t}}
$$


d) Berdasarkan hasil pengujian dengan menggunakan 3 pendekatan Common Effect Model (CEM), Fixed Effect Model (FEM) dan Random Effect Model (REM) didapatkan model FEM yang terbaik. Berdasarkan model FEM faktor yang berpengaruh signifikan adalah Indeks Pembangunan Manusia dan Pengeluaran Perkapita Disesuaikan.

\section{Daftar Pustaka}

[1] Baltagi, B. H. Econometrics Analysis of Panel Data Third Edition. Great Britain: Anthony Rowe Ltd, Chippenham, Wiltshire, 2005.

[2] BPS Indonesia. Berita Resmi Statistik Profil Kemiskinan di Indonesia September 2018, 2019.

[3] Greene. William H. Econometrics Analysis 6th Edition. New Jersey: Prentice Hall, 2007.

[4] Gujarati, Damodar N. Basic Econometrics Fourth Edition. New York: The McGraw-Hill Companies, 2004.

[5] Gujarati, Damodar N. Dasar-dasar Ekonometrika. Terjemahan: Mangunsong, R. C. Jakarta: Salemba Empat, 2012.

[6] Harinaldi. Prinsip-prinsip Statistik untuk Teknik dan Sains. Jakarta: Erlangga, 2005.

[7] Hsiao, C. Analysis Of Panel Data.Cambridge. Southern California: University Press, 2003.

[8] Setiawan \& Kusrini. Ekonometrika. Yogyakarta: Penerbit ANDI, 2010.

[9] Susanti, Sussy. Pengaruh Produk Domestik Regional Bruto, Pengangguran dan Indeks Pembangunan Manusia terhadap Kemiskinan di Jawa Barat dengan Menggunakan Analisis Data Panel. Jurnal Matematika Integratif, 9(1), 1-18, 2013.

[10] Widarjono, Agus. Ekonometrika Teori dan Aplikasi untuk Ekonomi dan Bisnis. Yogyakarta: Ekonisia FE UII, 2007.

[11] Widarjono, Agus. Ekonometrika: Pengantar dan Aplikasinya. Yogyakarta: Ekonisia, 2009.

[12] World Bank. Era Baru dalam Pengetasan Kemiskinan di Indonesia. Jakarta: Gradasi Aksara, 2006.

[13] Hufaini, A.S.F.R, Raupong, \& Ilyas, N. Regresi Model Data Panel Efek Tetap dengan Metode Within Group pada Data Indeks Pembangunan Manusia Provinsi Sulawesi Selatan. ESTIMASI: Journal of Statistics and Its Application, 1(1), 1020, 2020. 